\title{
INFLUENCE OF THE BRAKING SYSTEM THAT IS CONTRARY TO LEGISLATION ON BREAKING CHARACTERISTICS OF PASSENGER CAR
}

\begin{abstract}
There are also the vehicles among the other vehicles in road traffic that have been modified without being authorised by their producer. These also include modifications such as structural modifications in the vehicle break system. Besides a brake system of road motor vehicles is one of the main factors influencing the active safety of vehicles. The design of the brake system, its technical condition and additional intervention in its construction may have a positive as well as negative impact on the braking distance length and the value of the mean braking deceleration achieved. The paper focuses on the influence of the brake disc diameter of the front axle on the achieved value of the mean braking deceleration and the braking distance length, while the braking system has been modified for several times without being approved by car manufacturer. The introductory part of the paper describes the braking distance sections and it also explains the term of mean braking deceleration. The following part of the paper deals with the measurement methodology, measuring equipment and the vehicle used during the measurements as well as procedures employed. The results obtained from the measurements are processed and presented in tables and also in graphs for greater clarity. The final part of the paper summarizes and evaluates the measured results. The importance of the paper lies in quantification of the influence of brake discs with different diameters on the vehicle active safety in the case of a particular vehicle.
\end{abstract}

Keywords: active safety, brake system, brake disc, braking distance

Tomáš Skrúcaný1

${ }^{1}$ University of Žilina, Univerzitná 8215/1, $010 \quad 26$ Žilina, Slovakia; +421 41513 3518;

tomas.skrucany@fpedas.uniza.sk

František Synák ${ }^{2}$

${ }^{2}$ University of Žilina, Univerzitná 8215/1, $010 \quad 26 \quad$ Žilina, Slovakia; +421 41513 3523;

frantisek.synak@fpedas.uniza.sk

Štefánia Semanová ${ }^{3}$

${ }^{3}$ University of Žilina, Univerzitná 8215/1, $010 \quad 26 \quad$ Žilina, Slovakia; +42141513 3535;

stefania.semanova@fpedas.uniza.sk

\section{Introduction}

If a vehicle cannot move, this represents a problem. However, if it is already in motion and it cannot brake, the problem is much greater. The brake system fundamentally affects the level of vehicle active safety (Lazeet et al. 2016; Oyetubo, Afolabi, Ohida 2018). The design and technical condition of the brake system (Lagel et al. 2016) together with tyres (Selig et al. 2012) and other factors such as road surface (Metz 2016; Paraskevadakis et al. 2016) and slope influence (Mikušová 2017) the vehicle directional stability during braking and the braking distance length (Rievaj et al. 2013). The braking distance represents the distance which is travelled by a vehicle from the moment of pressing the brake pedal till the vehicle stops or till the moment when the driver stops applying the brake pedal (Zamzamzadeh et al. 2016) Fig. 1.

The total braking distance consists of the distance related to the driver perception and reaction time and the braking distance itself (Jammes et al. 2017). Further, the braking distance itself consists of the distance related to the brake system reaction time, initial braking and the distance travelled during full braking application effect (Gunney, Mutlu, Gavretli 2016).

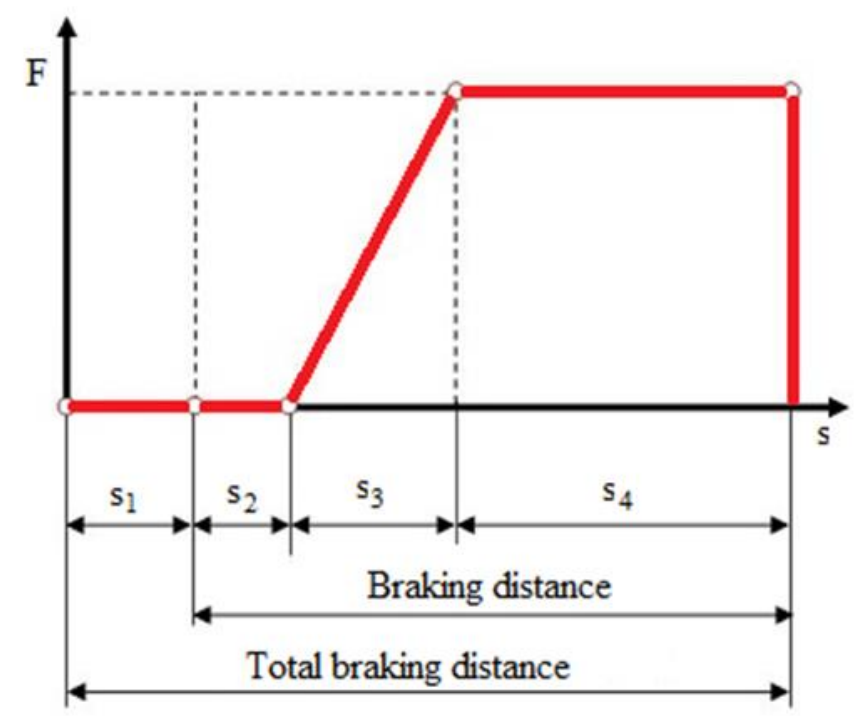

Fig. 1. The braking distance (Ondruš, Hockicko 2015)

The brake system reaction time represents the time interval elapsed from the moment of pressing the brake pedal until brake torque starts to act on wheels (Vrábel et al. 2017). It is the time during which all resistances are 
overcome and friction lining comes into the contact with friction surfaces which are friction surfaces of the brake disc in our case (Timur, Kuscu, Toylan 2017). The time interval from that moment till the moment of reaching full braking effect is called the initial braking (Gigan 2017). At the moment of full braking, the vehicle is continuously decelerated by the steady value of braking deceleration until it fully stops (Caban et al. 2016).

$$
M F D D=\frac{v_{b}^{2}-v_{e}^{2}}{25.92\left(s_{e}-s_{b}\right)}
$$

$v_{b}$ vehicle speed at $0.8 \cdot v_{1}\left(\mathrm{~km} \cdot \mathrm{h}^{-1}\right)$

$v_{e}$ vehicle speed at $0.1 \cdot v_{1}\left(\mathrm{~km} \cdot \mathrm{h}^{-1}\right)$

$s_{b}$ distance travelled between $v_{l}$ and $v_{b}(\mathrm{~m})$

$s_{e}$ distance travelled between $v_{l}$ and $v_{b}(\mathrm{~m})$ (Li et al. 2013)

Variable $v_{1}$ is considered to be initial vehicle speed i.e. the speed at the moment when the driver starts to act on the brake system controller (Li et al. 2013).

The aim of the paper is the measurement and quantification of the influence of the brake disc diameter on the value of mean braking deceleration as well as the braking distance length. The paper contains the methodology and the results of measurements with brake discs with different diameters of the front axle. The measurements were carried out by driving tests with the vehicle Volkswagen Golf II by using XL metre.

\section{Methodology}

The purpose of the measurement was to determine the influence of brake disc diameter on the braking distance length and on the achieved value of the mean braking deceleration MFDD. Three sets of front brake discs were used. The first set of brake discs was $239 \mathrm{~mm}$ in diameter, the second set contains the brake discs of $256 \mathrm{~mm}$ in diameter and the third set includes brake discs of $280 \mathrm{~mm}$ in diameter.

\section{Vehicle used for measurements}

The Volkswagen Golf II was used for the measurement, Fig. 2. The vehicle is not equipped with ABS system or any other similar electronic safety system. The technical parameters of the vehicle are given in Table 1.

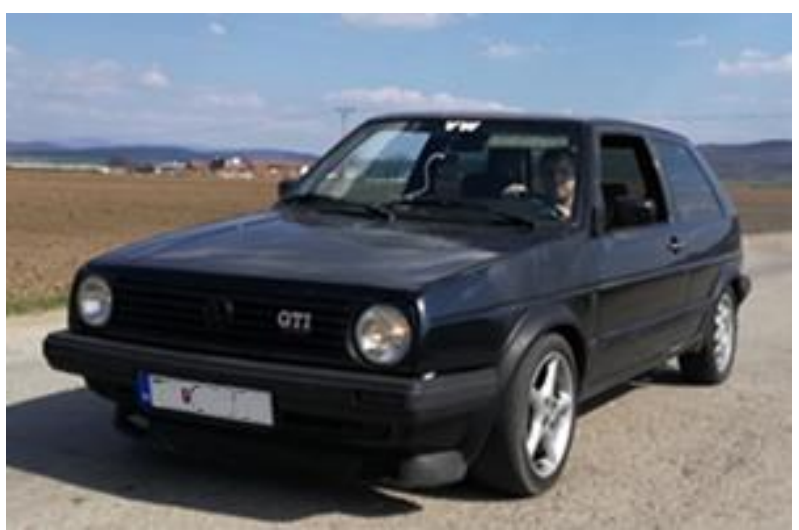

Fig. 2. The vehicle used for measurements

Table 1. Technical parameters of the vehicle

\begin{tabular}{ll}
\hline \hline manufacture year & 1991 \\
engine displacement & $1.6 \mathrm{dm}^{3}$ \\
fuel & diesel \\
body type & hatchback \\
vehicle dimensions & $3985 \mathrm{~mm} \times 665 \mathrm{~mm} \times 405 \mathrm{~mm}$ \\
vehicle curb weight & $915 \mathrm{~kg}$ \\
total vehicle weight & $1465 \mathrm{~kg}$ \\
vehicle weight during the & $1061 \mathrm{~kg}$ \\
measurement & disc, $226 \mathrm{~mm}$ \\
construction of rear brakes & summer, Bridgeston Turanza \\
tyres & $195 / 50 \mathrm{R} 1582 \mathrm{H}$ \\
& disc, $239 \mathrm{~mm}, 256 \mathrm{~mm}, 280 \mathrm{~mm}$ \\
front brakes & disc, $226 \mathrm{~mm}$ \\
rear brakes &
\end{tabular}

The vehicle is equipped with a Volkswagen Golf III main brake cylinder and a controller of brake effect of the rear axle.

\section{Measuring equipment}

The equipment used for the measurement was XL metre Pro Gamma with recording frequency from $25 \mathrm{~Hz}$ up to $200 \mathrm{~Hz}$, Fig. 3. This electronic device is batterypowered and provides the ability to evaluate the data via a PC.

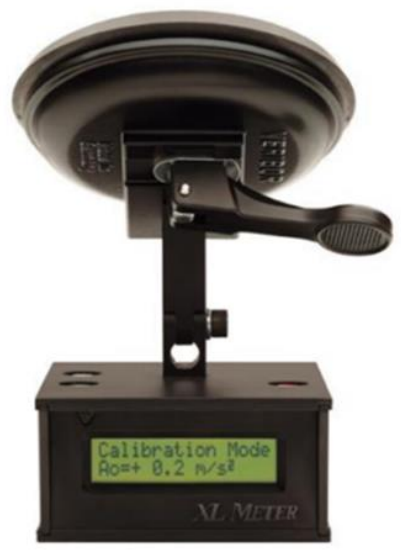

Fig. 3. Device XL metre used during measurements 
The basic measuring range in the longitudinal and transverse axe is from $-14 \mathrm{~m} \cdot \mathrm{s}^{-2}$ to $+14 \mathrm{~m} \cdot \mathrm{s}^{-2}$. The device records the following parameters:

1) braking distance $S_{0}(m)$,

2) braking time $t_{b r}(s)$,

3) initial speed $V_{0}\left(\mathrm{~m} \cdot \mathrm{s}^{-1}\right)$,

4) mean braking deceleration MFDD $\left(\mathrm{m} \cdot \mathrm{s}^{-2}\right)$.

\section{Measurement procedure}

The proper tyre inflation was checked prior measurements. The measurement procedure was as follows:

1) Heating up the brakes and tyres to the operating temperature.

2) Fixing of XL metre on the windscreen.

3) Calibration of XL metre.

4) Reaching the specified vehicle speed.

5) Full braking of the vehicle after reaching the specified speed.

6) Complete stopping of the vehicle.

7) Saving the measured data.

Each measurement was repeated three times for the following speed ranges: $40 \mathrm{~km} \cdot \mathrm{h}^{-1}, 60 \mathrm{~km} \cdot \mathrm{h}^{-1}$ and 80 $\mathrm{km} \cdot \mathrm{h}^{-1}$. Subsequently, brake discs of different diameter were mounted and the measurements were repeated.

\section{Measured data}

The data obtained by measurements are shown in the following tables (Tables $2-9$ ). The tables contain the mean braking deceleration MFDD, braking distance length $S_{0}$, initial vehicle speed $V_{0}$ and braking time $t_{B R}$. During the measurements at speed of $80 \mathrm{~km} \cdot \mathrm{h}^{-1}$, significant vehicle directional instability was observed in the case of brake discs with diameter of $239 \mathrm{~mm}$, and therefore the data from this measurement were not evaluated.

Table 2. Measurement with brake discs $256 \mathrm{~mm}$ at speed $40 \mathrm{~km} \cdot \mathrm{h}^{-1}$

\begin{tabular}{lllll}
\hline \hline & MFDD $\left(\mathrm{m} \cdot \mathrm{s}^{-2}\right)$ & $\mathrm{S}_{0}(\mathrm{~m})$ & $\mathrm{V}_{0}\left(\mathrm{~km} \cdot \mathrm{h}^{-1}\right)$ & $\mathrm{t}_{\mathrm{BR}}(\mathrm{s})$ \\
\hline 1 & 5.39 & 12.81 & 39.43 & 2.23 \\
2 & 5.48 & 13.66 & 40.80 & 2.31 \\
3 & 5.28 & 13.58 & 40.08 & 2.33 \\
average & 5.38 & 13.35 & 40.10 & 2,29 \\
\hline \hline
\end{tabular}

Table 3. Measurement with brake discs $256 \mathrm{~mm}$ at speed $40 \mathrm{~km} \cdot \mathrm{h}^{-1}$

\begin{tabular}{lllll}
\hline \hline & MFDD $\left(\mathrm{m} \cdot \mathrm{s}^{-2}\right)$ & $\mathrm{S}_{0}(\mathrm{~m})$ & $\mathrm{V}_{0}\left(\mathrm{~km} \cdot \mathrm{h}^{-1}\right)$ & $\mathrm{t}_{\mathrm{BR}}(\mathrm{s})$ \\
\hline 1 & 5.85 & 12.65 & 39.84 & 2.19 \\
2 & 6.13 & 11.86 & 40.40 & 2.00 \\
3 & 5.79 & 12.76 & 40.30 & 2.08 \\
& 5.92 & 12.42 & 40.18 & 2.09 \\
\hline
\end{tabular}

Table 4. Measurement with brake discs $280 \mathrm{~mm}$ at speed $40 \mathrm{~km} \cdot \mathrm{h}^{-1}$

\begin{tabular}{|c|c|c|c|c|}
\hline & $\operatorname{MFDD}\left(\mathrm{m} \cdot \mathrm{s}^{-2}\right)$ & $\mathrm{S}_{0}(\mathrm{~m})$ & $\begin{array}{l}\mathrm{V}_{0} \\
\left.{ }^{1}\right)\end{array} \quad\left(\mathrm{km} \cdot \mathrm{h}^{-}\right.$ & $t_{\mathrm{BR}}(\mathrm{s})$ \\
\hline 1 & 8.54 & 9.11 & 39.29 & 1.51 \\
\hline 2 & 7.90 & 10.44 & 39.89 & 1.67 \\
\hline 3 & 8.26 & 8.89 & 40.31 & 1.50 \\
\hline average & 8.23 & 9.48 & 39.83 & 1.56 \\
\hline
\end{tabular}

Table 5. Measurement with brake discs $239 \mathrm{~mm}$ at speed $60 \mathrm{~km} \cdot \mathrm{h}^{-1}$

\begin{tabular}{lllll}
\hline \hline & MFDD $\left(\mathrm{m} \cdot \mathrm{s}^{-2}\right)$ & $\mathrm{S}_{0}(\mathrm{~m})$ & $\mathrm{V}_{0}\left(\mathrm{~km} \cdot \mathrm{h}^{-1}\right)$ & $\mathrm{t}_{\mathrm{BR}}(\mathrm{s})$ \\
\hline 1 & 5.03 & 31.17 & 59.25 & 3.54 \\
2 & 4.93 & 39.49 & 59.39 & 4.16 \\
3 & 5.51 & 32.41 & 59.71 & 3.56 \\
average & 5.16 & 34.36 & 59.45 & 3.75 \\
\hline \hline
\end{tabular}

Table 6. Measurement with brake discs $256 \mathrm{~mm}$ at speed $60 \mathrm{~km} \cdot \mathrm{h}^{-1}$

\begin{tabular}{lllll}
\hline \hline & MFDD $\left(\mathrm{m} \cdot \mathrm{s}^{-2}\right)$ & $\mathrm{S}_{0}(\mathrm{~m})$ & $\mathrm{V}_{0}\left(\mathrm{~km} \cdot \mathrm{h}^{-1}\right)$ & $\mathrm{t}_{\mathrm{BR}}(\mathrm{s})$ \\
\hline 1 & 6.78 & 24.45 & 59.02 & 3.42 \\
2 & 6.31 & 29.94 & 59.30 & 3.48 \\
3 & 7.31 & 22.39 & 59.55 & 2.44 \\
average & 6.80 & 25.59 & 59.29 & 3.11 \\
\hline \hline
\end{tabular}

Table 7. Measurement with brake discs $280 \mathrm{~mm}$ at speed $60 \mathrm{~km} \cdot \mathrm{h}^{-1}$

\begin{tabular}{lllll}
\hline & MFDD $\left(\mathrm{m} \cdot \mathrm{s}^{-2}\right)$ & $\mathrm{S}_{0}(\mathrm{~m})$ & $\mathrm{V}_{0}\left(\mathrm{~km} \cdot \mathrm{h}^{-1}\right)$ & $\mathrm{t}_{\mathrm{BR}}(\mathrm{s})$ \\
\hline 1 & 7.92 & 24.60 & 60.48 & 2.66 \\
2 & 6.85 & 28.39 & 61.09 & 2.95 \\
3 & 6.73 & 23.96 & 59.25 & 2.75 \\
\multirow{2}{*}{ average } & 7.17 & 25.65 & 60.27 & 2.79 \\
\hline \hline
\end{tabular}

Table 8. Measurement with brake discs $256 \mathrm{~mm}$ at speed $80 \mathrm{~km} \cdot \mathrm{h}^{-1}$

\begin{tabular}{lllll}
\hline \hline & MFDD $\left(\mathrm{m} \cdot \mathrm{s}^{-2}\right)$ & $\mathrm{S}_{0}(\mathrm{~m})$ & $\mathrm{V}_{0}\left(\mathrm{~km} \cdot \mathrm{h}^{-1}\right)$ & $\mathrm{t}_{\mathrm{BR}}(\mathrm{s})$ \\
\hline 1 & 6.80 & 48.83 & 78.93 & 4.10 \\
2 & 6.53 & 45.12 & 79.15 & 4.23 \\
3 & 6.73 & 43.82 & 80.37 & 3.78 \\
average & 6.69 & 45.92 & 79.48 & 4.04 \\
\hline \hline
\end{tabular}

Table 9. Measurement with brake discs $280 \mathrm{~mm}$ at speed $80 \mathrm{~km} \cdot \mathrm{h}^{-1}$

\begin{tabular}{lllll}
\hline & MFDD $\left(\mathrm{m} \cdot \mathrm{s}^{-2}\right)$ & $\mathrm{S}_{0}(\mathrm{~m})$ & $\mathrm{V}_{0}\left(\mathrm{~km} \cdot \mathrm{h}^{-1}\right)$ & $\mathrm{t}_{\mathrm{BR}}(\mathrm{s})$ \\
\hline 1 & 6.91 & 47.26 & 78.34 & 3.98 \\
2 & 6.20 & 68.16 & 80.77 & 5.04 \\
3 & 6.51 & 43.86 & 80.17 & 3.94 \\
\multirow{2}{*}{ average } & 6.54 & 53.09 & 79.76 & 4.32 \\
\hline \hline
\end{tabular}

The results obtained from the measurements are processed also in graphs for greater clarity, Fig. 4 and Fig. 5. The graphs provide information about MFDD and 
braking distance length depending on the initial vehicle speed and brake disc diameter used.

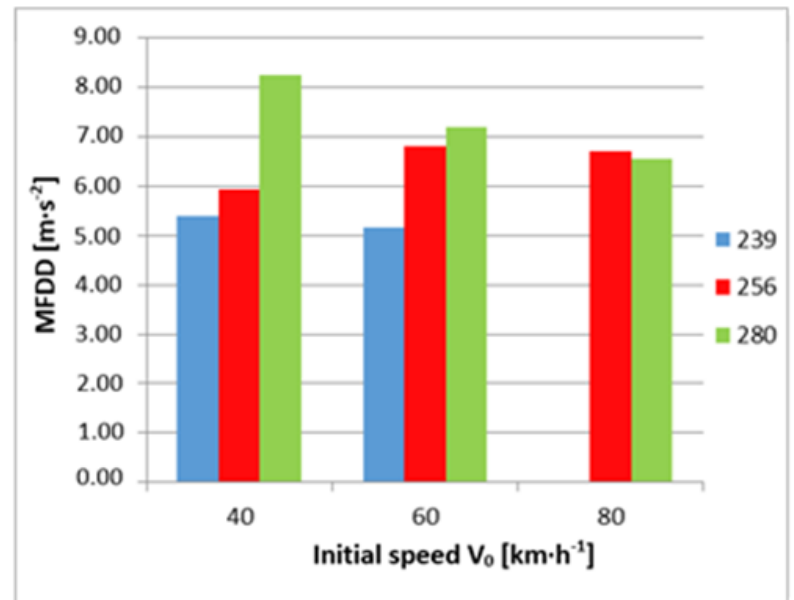

Fig. 4. MFDD depending on the initial vehicle speed and brake disc diameter used

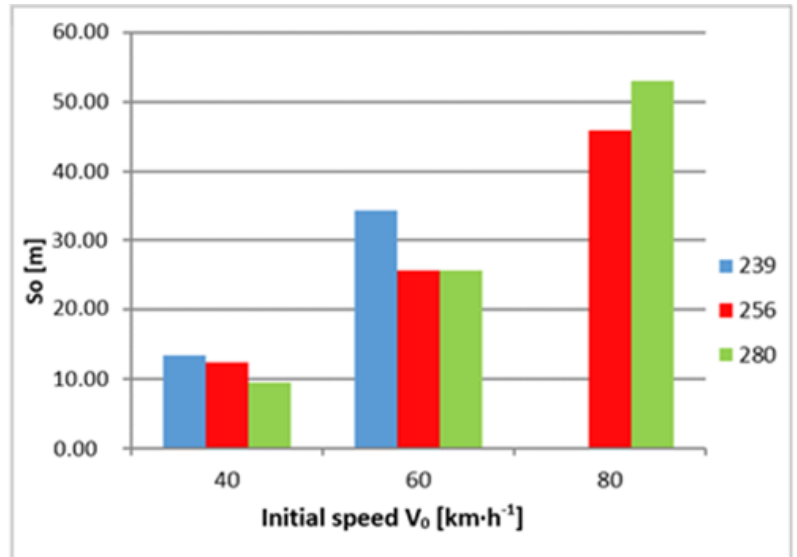

Fig. 5. So depending on the initial vehicle speed and brake disc diameter used

\section{Results}

As it can be seen in previous tables and graphs, the brake disc diameter plays a significant role in achieved value of the mean braking deceleration as well as the braking distance length. In case of the replacement of the brake discs of $239 \mathrm{~mm}$ in diameter with the brake discs of $256 \mathrm{~mm}$ in diameter, no significant changes were observed. However, the largest changes in MFDD and $\mathrm{S}_{0}$ were measured when changing the $256 \mathrm{~mm}$ brake disc diameter with $280 \mathrm{~mm}$ brake disc diameter. At speed 40 $\mathrm{km} \cdot \mathrm{h}^{-1}$, this brake disc change caused an increase in MFDD by $2.31 \mathrm{~m} \cdot \mathrm{s}^{-2}$ which resulted in braking distance reduction by $2.94 \mathrm{~m}$. In the case of replacement of the brake discs of $256 \mathrm{~mm}$ in diameter with the brake discs of $280 \mathrm{~mm}$ in diameter, the braking distance was reduced by $23 \%$ at the mentioned speed. During measurements of braking from higher initial speed $60 \mathrm{~km} \cdot \mathrm{h}^{-1}$ and $80 \mathrm{~km} \cdot \mathrm{h}^{-1}$ respectively, the measured differences were significantly smaller. For instance at speed of $80 \mathrm{~km} \cdot \mathrm{h}^{-1}$, the brake disc of smaller diameter $(256 \mathrm{~mm})$ caused the higher measured value of MFDD in comparison with the brake disc of $280 \mathrm{~mm}$ in diameter. This fact can be explained that there probably was not sufficient long time period between two measurements and thus the brake disc diameter of $280 \mathrm{~mm}$ was overheated and it was not cooled down to the operating temperature (Rievaj, Mokričková, Synák 2017). Brake discs with a diameter of $239 \mathrm{~mm}$ can be evaluated as inappropriate because locking of the rear axle wheels and vehicle directional instability were observed while braking from the initial speed of $80 \mathrm{~km} \cdot \mathrm{h}^{-1}$. The vehicle with these brake discs mounted did not achieve the MFDD value stipulated by legislation i.e. the value of $5.8 \mathrm{~m} \cdot \mathrm{s}^{-2}$.

\section{Conclusion}

Many factors have an impact on the course of braking, the braking distance length and the mean braking deceleration value. Based on the results presented in the paper, one of these factors is also a brake disc diameter. The diameter of brake discs may have an influence on the traffic accident occurrence or accident consequences. When interpreting the measurement results, it is necessary to take into account two facts which affected these results. The first one is the absence of electronic safety systems in the vehicle used for measurements. If the vehicle was equipped with an antilock wheel system, the locking of rear axle wheels would not occur and thus the resultant values would be different (Haugland 2013). Although, the vehicle was equipped with a rear axle load regulator compared to the serial vehicle, the locking of rear axle wheels occurred when using the brake disc of $239 \mathrm{~mm}$ in diameter. The second fact represents the additional mounting of the disc brakes on the rear axle instead of the origin manufacturer solution with drum brakes. In conjunction with the absence of the anti-lock system (Zhao 2014), this fact caused the locking of rear axle wheels while using brake disc diameter of $239 \mathrm{~mm}$ and this results in a negative impact on active vehicle safety. In terms of legislation, the results confirm the eligibility of the prohibition to carry out such interventions in the vehicle design which is not approved by the manufacturer.

\section{Acknowledgment}

This article was created to support project named as:

6/KCMD/2018 - Vplyv aerodynamických vlastností vozidiel v cestnej doprave na ich prevádzku (6/KCMD/2018 - Influence of road vehicles aerodynamical characteristics on their operation) 
And

5/KCMD/2018 - Skúmanie priebehu závislosti „siladeformácia" pri namáhaní vybraného modelu $(5 / \mathrm{KCMD} / 2018$ - Examination of process of the forcedeformation dependence on selected model)

And

Centre of excellence for systems and services of intelligent transport II.,

ITMS 26220120050 supported by the Research \& Development Operational Programme funded by the ERDF.

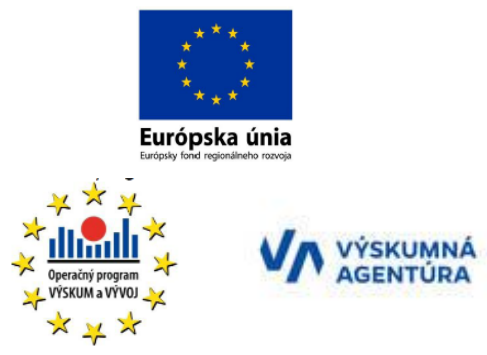

\section{References}

Caban, J. et al. 2016 The research on ageing of glycol - based brake fluids of vehicles in operation. In: Advacnec in Science and Technology - Research Journal. Vol: 10, pp: 9 - 16, DOI: 10.12913/22998624/65113.

Gigan, L. 2017 Improvement in the brake disc design for heavy vehicles by parametric evaluation. In: Proceedings of the institution of mechanical engineers part $D$ - journal of automobile angineering. Vol: 231, pp: 1989 - 2004, DOI: 10.1177/0954407016688421.

Guney, B., Mutlu, I., Gayretli, A. 2016 Investigation of braking performance of NiCrBSi coated brake discs by flame spraying. In: Journal of the Balkan Tribological Association, vol: 22, pp: $887-903$.

Haugland, O. 2013 Car stopping distance on a tabletop. In: Physics teacher, Vol: 51, pp: $268-268$.

Ondruš, J., Hockicko P. 2015 Braking deceleration measurement using the video analysis of motions by $\mathrm{Sw}$ tracker. In: Transport and Telecommunication, Vol: 16, pp: $127-137$.

Jammes, Y. et al. 2017 Emergency braking is affected by the use of cruise control. In: Traffic Injury Prevention, Vol: 18, $\quad$ pp: $636 \quad-\quad 641, \quad$ DOI: $10.1080 / 15389588.2016 .1274978$.

Lagel, M. et al. 2016 Automotive brake pads made with a bioresin matrix. In: Industrial Crops and Products, Vol: 85, pp: 372 - 381, DOI: 10.1016/j.indcrop.2015.12.090.

Lazeet, D. et al. 2016 Analysis of truck braking system in terms of construction and operation. In: Acta technica napocensis series - aplied mathematics mechanics and engineering, Vol: 59, pp:209-218.

Li, E. et al. 2013 Influences of initial braking velocity and passenger capacity on Mean Fully Developed Deceleration. In: Mechanical engineering an materials, Vol: 281, 201 p: DOI: 10.4028/www.scientific.net/AMM.281.201.

Li, W. et al. 2013 Vehicle Braking Efficiency On-Line Monitoring and Evaluation with MFDD. In: Advances designs and researches for manufacturing, PTS 1-3, Vol: 605 - 607, pp_ $_{-}$968, DOI: 10.4028/www.scientiAMR.605-607.968.

Metz, L. 2016 Friction on Polished vs. Newly Re-Rocked Oiland-Chip Roadway Surfaces. In: SAE international journal of passenger cars - mechanical systems. Vol: 9, pp: 541 - 545, DOI: 10.4271/2016-01-1568.

Mikušová, M. 2017 Crash avoidance systems and collision safety devices for vehicle occupants. In: Dynamics of civil engineering and transport structures and wind engineering. Vol: $\quad 107, \quad$ DOI: 10.1051/matecconf/201710700024.

Oyetubo, A., Afolabi, O., Ohida, M. 2018 Analysis of Road Traffic Safety in Minna Niger State, Nigeria. In: Logistics \& Sustainable Transport, 9(1), pp. 23-38. DOI:10.2478/jlst-2018-0003.

Paraskevadakis, D. et al. 2016 The impact of transport infrastructure projects on sustainable development within a major logistics gateway in North West England. In: Logistics \& Sustainable Transport, 7(1), pp. 28-40. DOI:10.1515/jlst-2016-0003.

Rievaj, V. et al. 2013 Tire inflation pressure influence on a vehicle stopping distances. In: International Journal of Traffic and Transportation Engineering. Vol: 2 pp: 9 - 13 Doi:10.5923/j.ijtte.20130202.01.

Rievaj, V., Mokričková, Synák, F. 2017 Temperature of the brakes and the braking force In: Transport and communications : scientific journal.. - Vol. 5, no. 1, pp: 16 - 16, ISSN 1339-5130.

Selig, M. et al. 2012 The influence of tyre contact patch and on the stopping distance of automotive vehicles. In: 25 th International Congress on Condition Monitoring and Diagnostic Engineering (COMADEM), Vol: 364, DOI: 10.1088/1742-6596/364/1/012014.

Timur, M., Kuscu, H., Toylan H. 2017 Design and manufacture of automated controlled test machine detecting braking characteristic of brake lining in vehicles. In: Proceedings of the institution of mechanical engineers part $C$-Journal of mechanical engineering science. Vol: 231, pp: $3318-$ 3329, DOI: 10.1177/0954406216645128.

Vrábel, J. et al. 2017 Influence of Emergency Braking on Changes of the Axle Load of Vehicles Transporting Solid Bulk Substrates. In: Transbaltica 2017: Transportation and technology, Vol: 187, pp: 89 - 99, DOI: 10.1016/j.proeng.2017.04.354.

Zamzamzadeh, M. et al. 2016 Dynamic simulation of brake pedal force effect on heavy vehicle braking distance under wet road conditions. In: International Journal of Automotive and Mechanical Engineering, Vol: 13, pp: 3555 - 3563, DOI: 10.15282/ijame.13.3.2016.2.0292.

Zhang, L. et al. 2016 All-Wheel Braking Force Allocation During a Braking-in-Turn Maneuver for Vehicles With the Brake-by-Wire System Considering Braking Efficiency and Stability. In: IEFE Transactions on Vehicular Technology, Vol: 265, pp: 4752 - 4767, DOI: 10.1007/978-3-319-24577-5_17.

Zhao, L. 2014 Vehicle Braking Stability Analysis in Turn Condition. In: Machines Design and manufacturing Engineering III, pp: 604 - 607, llos, A., Al-Hadithi, M., 1992. Driver behaviour during onset of amber at signalised junctions. Traffic Engineering and Control 33 (5), 312e317. 